\title{
Characterization of test specimens produced in reduced size for X-ray microtomography $(\mu-\mathrm{CT})$ tests
}

\section{Caracterização de corpos de prova de tamanho reduzido desenvolvidos para ensaios de microtomografia de raios $X(\mu-C T)$}
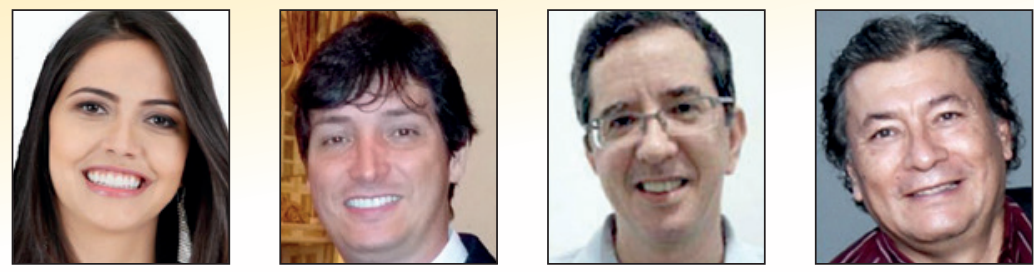

E. E. BERNARDES a elenbernardes@gmail.com

A. G. DE MAGALHÃES a aldom@ufmg.br

W. L. VASCONCELOS wlv@demet.br
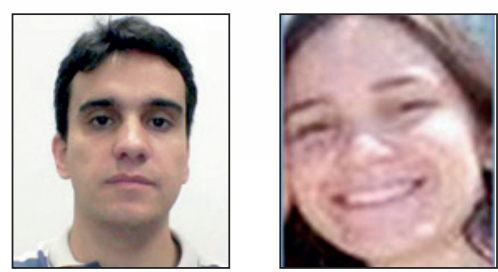

E. V. M. CARRASCO' mantilla@dees.ufmg.br

E. H. M. NUNES b eduardohmn@gmail.com

L. B. DE LIMA lublbh@gmail.com

\begin{abstract}
The need to use reduced sample sizes, in order to attain improved spatial resolution in ( $\mu$-CT) tests applied in Portland cement composites, makes researchers perform the fractionation of materials to obtain samples with dimensions compatible with the capacity of the scanning equipment, which might cause alterations in the microstructure under analysis. Therefore, a test specimen (TS) with dimensions compatible with the scanning capacity of a microtomography system that operates with an X-ray tube and voltage ranging from 20 to $100 \mathrm{kV}$ was proposed. Axial compression strength tests were made and their total porosity was assessed by an apparent density and solid fraction density ratio, which were obtained by means of mercury and helium pycnometry and $\mu$-CT technique, respectively. The adoption of that TS has shown to be viable for providing a sample with a higher level of representation.
\end{abstract}

Keywords: X-ray microtomography, fractionation of samples, test specimen, pycnometry, pore structure.

\section{Resumo}

A necessidade de se utilizar amostras de tamanho reduzido, para a obtenção de uma melhor resolução espacial nos ensaios de $\mu$-CT em compósitos de cimento Portland, leva os pesquisadores a realizar o fracionamento do material para a obtenção de amostras com dimensões compatíveis com a capacidade de leitura do equipamento, o que pode ocasionar alterações da microestrutura em análise. Assim, foi proposto um corpo de prova (CP) com dimensões compatíveis com a capacidade de leitura de um microtomógrafo com tubo de raios $\mathrm{X}$ que opera dentro de um intervalo de tensão de 20 a 100 kV.Foram realizados testes de resistência à compressão axial e avaliação da sua porosidade total por meio da relação entre a densidade aparente e a densidade da fração sólida, obtidas respectivamente pelas técnicas de picnometria (de mercúrio e hélio) e pela técnica de $\mu$-CT. A adoção deste CP se mostrou viável por proprocionar uma amostragem com maior nível de representatividade.

Palavras-chave: microtomografia de raios X; fracionamento de amostras, corpo de prova, picnometria, estrutura de poros. 


\section{Introduction}

The use of computer based X-ray microtomography ( $\mu-\mathrm{CT}$ ) has vastly improved the structural analysis of pores in materials. According to Cnudde et al. [1], a critical point when working with X-ray microtomography is the ratio between the size of the sample and the spatial resolution obtained. A small sample size is required to attain a high spatial resolution. However, working with small samples conflicts with the question of representativeness, since the volume of the sample must contain the properties of the whole set, in order to obtain an acceptable estimate of the general properties of the material. In the case of composites of a cement matrix, their heterogeneity and complex void structure increase the level of difficulty of developing an adequate sampling plan.

Studies involving the analysis of pores in cementitious matrix composites by using X-ray microtomography make use of several different sampling techniques. In general, the methodologies adopted in these studies involve the molding of test specimens from which the samples are extracted. To perform this extraction, the processes of fragmentation or extraction of testimony are mainly used [2-4]. However, these processes may lead to micro-fissures, thus causing alterations in the microstructure of the materials. Additionally, a sample collected from a specific region of the specimen (TS), for instance, from the central region [5], may produce results that are not consistent with the system's true properties.

A possible alternative to extracting samples could be molding specimens with a reduced size that is compatible with the reading capacity of the equipment [5-7], which would furnish increased sampling/TS ratio, or even a total sampling.

However, it is important to note that a reduced size increases the level of difficulty in conducting studies with concretes, since the presence of coarse aggregates makes it more difficult to produce very small specimens. Therefore, studies in this field usually use materials that feature a cementitious base such as cement mortars, grouts and micro-concretes.

The objective of this study was to produce mortar specimens with a reduced size, viable to be used in $\mu$-CT studies using whole and intact structures. In addition to that, it was sought to evaluate if the internal structure of these CPs could be considered representative when compared to specimens with dimensions of $(5 \times 10) \mathrm{cm}$,
Table 1

CP V ARI chemical analysis according to NBR 5733 standard

\begin{tabular}{|c|c|c|}
\hline $\begin{array}{c}\text { Chemical } \\
\text { determinations }\end{array}$ & $\begin{array}{c}\text { Cement used } \\
\text { (\% of the mass) }\end{array}$ & $\begin{array}{c}\text { NBR 5733 limits } \\
\text { (\% of the mass) }\end{array}$ \\
\hline $\begin{array}{c}\text { Insoluble residue } \\
\text { (IR) }\end{array}$ & 0.79 & $\leq 1.0$ \\
\hline $\begin{array}{c}\text { Loss on ignition } \\
\text { (LOI) }\end{array}$ & 3.9 & $\leq 4.5$ \\
\hline $\begin{array}{c}\text { Magnesium } \\
\text { oxide (MgO) }\end{array}$ & 0.76 & $\leq 3.5$ \\
\hline $\begin{array}{c}\text { Sulfur trioxide } \\
\left(\mathrm{SO}_{3}\right)\end{array}$ & 2.89 & $\leq 4.5$ \\
\hline $\begin{array}{c}\text { - when C3A of } \\
\text { the clinker - 8\% }\end{array}$ & - & $\leq 3.0$ \\
\hline $\begin{array}{c}\text { - when C3A of } \\
\text { the clinker }>8 \%\end{array}$ & 2.48 & \\
\hline $\begin{array}{c}\text { Carbon dioxide } \\
\left(\mathrm{CO}_{2} \text { ) }\right.\end{array}$ & & \\
\hline
\end{tabular}

produced from the procedure specified by standard NBR 7215 [8]. The adoption of a standardized procedure aims to reduce the degree of variability of the study, facilitating the comparison of results for future researches.

The dimensions of the small size CPs were determined by preliminary tests performed in the same $\mu$-CT equipment used in the subsequent assays. It was sought the largest diameter which, according to the power of the equipment, allowed to overcome the degree of opacity of the material to X-ray. For definition of the height, it was respected the condition defined in standard NBR 5738 [9] wich says that the ratio between height/diameter of the test specimen must be equal to 2 . Thus, the feasibility of testing cylindrical CPs of $(2 \times 4) \mathrm{cm}$ was observed.

For the two types of TS adopted, axial compression tests were performed, besides to evaluating its total porosity by means of the relation between the bulk density (apparent) and the density of the solid fraction, obtained by the techniques of mercury and helium

\section{Table 2}

CPV ARI mechanical analysis according to NBR 5733 standard

\begin{tabular}{|c|c|c|c|c|}
\hline \multicolumn{2}{|c|}{ Characteristics and properties } & Unit & Cement used & Cement used \\
\hline \multirow{2}{*}{ Fineness } & \multirow{2}{*}{$\begin{array}{c}\text { Residue in the sieve } 75 \mu \mathrm{m} \\
\text { Specific area }\end{array}$} & $\%$ & $\leq 6$ & $\leq 6$ \\
\hline & & $\mathrm{m}^{2} / \mathrm{kg}$ & 480.6 & $\geq 300$ \\
\hline \multicolumn{2}{|c|}{ Mortar setting start time } & $\min$ & 131 & $\geq 60$ \\
\hline \multicolumn{2}{|c|}{ Mortar setting end time } & $\min$ & 186 & $\leq 600$ \\
\hline \multicolumn{2}{|c|}{ Expandability when hot } & $\mathrm{mm}$ & $\leq 5$ & $\leq 5$ \\
\hline \multirow{3}{*}{$\begin{array}{l}\text { Compressive } \\
\text { strength }\end{array}$} & 1 day old & $\mathrm{MPa}$ & 27.9 & $\geq 14$ \\
\hline & 3 days old & $\mathrm{MPa}$ & 40.2 & $\geq 24$ \\
\hline & 7 days old & $\mathrm{MPa}$ & 45.1 & $\geq 34$ \\
\hline
\end{tabular}


pycnometry and the $\mu-C T$ technique, respectively. The evaluation of the porosity by means of the $\mu$-CT technique was performed only in the small size $\mathrm{CP}$, since the equipment does not have sufficient power for reading in the $\mathrm{CP}$ of $(5 \times 10) \mathrm{cm}$.

In order to compare the results obtained from axial compressive strength tests, performed in the two TS groups studied, in order to evaluate the effect caused by the reduction in size, it was used the hypothesis test based on the Student $t$ Test probability distribution (or T-statistical test) for independent samples.

For the purpose of verification, a new hypothesis test was performed using the Fisher-Snedecor probability distribution test (test F). For the purpose of verification, a new hypothesis test was performed using the Fisher-Snedecor probability distribution test (F-test).

\section{Materials and experimental program}

\subsection{Mortar}

Portland cement with high initial strength (CP V - ARI), whose chemical and physical properties analyses are presented in Tables 1 and 2, respectively, according to the standard NBR 5733 [10], was used. This choice is caused by the fact that this is the cement with lower content of additions available in the Brazilian market.

The mortar was produced using a 1:3 (cement/sand) ratio with a 0.48 water/cement $(\mathrm{w} / \mathrm{c})$ ratio. The sand utilized was prepared from a homogenized mixture of four individual fractions of regular sand in equal proportions, in mass, as specified in the standard NBR 7215 [8]. Table 3 exhibits the granulometric fractions of the regular sand, according to the standard NBR 7214 [11].

\subsection{Molding and curing}

In the preparation of the specimens (TS), standard $(5 \times 10) \mathrm{cm}$ molds and special $(2 \times 4) \mathrm{cm}$ molds were used, whose images can be seen in Figure 1. The specimen diameter $2 \mathrm{~cm}$ was previously established based on the opacity level of the material under study in relation to reading capacity of the $\mu-C T$ equipment to be utilized [6].

For the compression strength test, 55 cylindrical specimens featuring $2 \times 4 \mathrm{~cm}$ dimensions and 56 specimens featuring $5 \times 10 \mathrm{~cm}$ dimensions were molded, ruptured at 7 days of age. The compression strength tests on the normalized TS with dimensions of $(5 \times 10) \mathrm{cm}$ have the purpose of validating the material, the dosing procedure and preparation of the samples, adopted in this study, since its results are backed by standard [10] and literature. Thus, when ap-

\section{Table 3}

Grain size fractions standard sand

\begin{tabular}{|c|c|}
\hline $\begin{array}{c}\text { Material trapped } \\
\text { between the nominal } \\
\text { aperture sieve }\end{array}$ & Designation \\
\hline $2.4 \mathrm{~mm}$ to $1.2 \mathrm{~mm}$ & Coarse fraction \\
\hline $1.2 \mathrm{~mm}$ to $0.6 \mathrm{~mm}$ & Mean coarse fraction \\
\hline $0.6 \mathrm{~mm}$ to $0.3 \mathrm{~mm}$ & Mean fine fraction \\
\hline $0.3 \mathrm{~mm}$ to $0.15 \mathrm{~mm}$ & Fine fraction \\
\hline
\end{tabular}

plying the same procedures for CP with dimensions of $(2 \times 4) \mathrm{cm}$, it is possible to perform a comparison of results, since there is no standard or literature data for specimens with these dimensions. Samples used in the helium gas $(\mathrm{He})$ and mercury $(\mathrm{Hg})$ pycnometry tests were collected from the same specimen. Therefore, for each age under analysis ( 7 and 28 days), unique specimens were molded featuring $2 \times 4 \mathrm{~cm}$ and $5 \times 10 \mathrm{~cm}$.

For reading with the $\mathrm{X}$-ray microtomography, one test specimen with dimensions of $(2 \times 4) \mathrm{cm}$ was molded, being used at both test ages ( 7 and 28 days). Because it is a non-destructive technique, the performance of readings at different ages, using the same test body, besides being feasible is convenient, as it allows following the actual changes in the porosity of the material due to the cement particles hydration process, without any variability arising from the molding process.

In the molding of the specimens, the mechanical densification was used, by means of a vibrating table, in order to reduce the variability in the process.

After the molding step, the test specimens were kept in a humid chamber for a period of 24 hours and then demolded and kept submerged in a tank containing potable water until ready to be tested.

\subsection{Preparing the test specimens}

For the compressive strength test, all TS had their ends capped with sulfur, in order to guarantee the parallelism between them. For the pycnometry tests, it was necessary to establish a specific preparation procedure for each TS size.

The specimens of $(2 \times 4) \mathrm{cm}$ were divided in two halves by a longitudinal section. One of the halves was utilized in the helium pycnometry test and the other one in the mercury pycnometry test. In the specimens with dimensions of $(5 \times 10) \mathrm{cm}$, two orthogonal cuts were made between them, in the longitudinal direction, and a cross section, resulting in a division of 8 parts with similar dimensions. Figure 2 shows the schematic model of cutting of the CPs and the indication of the parts selected for the tests. By longitudinal division, $1 / 4$ of the specimen was selected for the He pycnometry

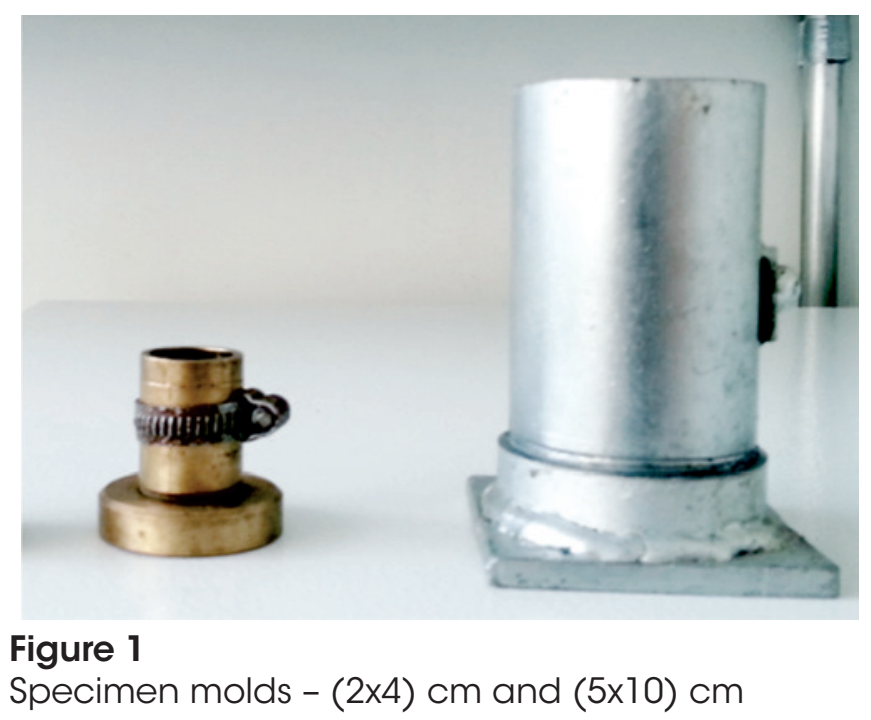




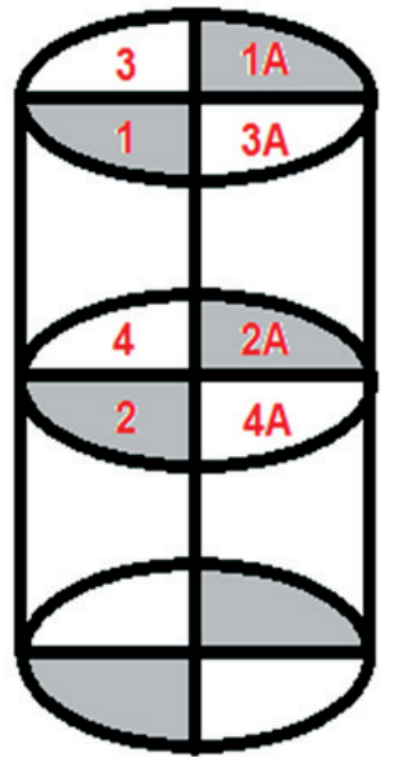

\section{Figure 2}

Cutting diagram of the $\mathrm{CP}(5 \times 10) \mathrm{cm}$

test (parts 1 and 2 ) and the other $1 / 4$, opposite the vertex of the first sample, was reserved for the $\mathrm{Hg}$ pycnometry test (parts $1 \mathrm{~A}$ and $2 \mathrm{~A}$ ), and the remaining parts were discarded.

Samples for the pycnometry tests were oven dried at a temperature of $(105 \pm 5)^{\circ} \mathrm{C}$ for a period of approximately 6 hours. This drying time was sufficient for two successive weighings, intervals in 1 hour, not to differ by more than $0.5 \%$ from the lowest mass.

The parts for the helium pycnometry test were pulverized in an agate mortar grinder mill until a grain size of less than $75 \mu \mathrm{m}$ be attained, and controlled by sieving $(100 \%$ of the material passing through the sieve \# 200). At the end of the milling step, the material was homogeneously fractioned in order to obtain a fraction of approximately 3.6 grams.

The test specimen intended for the $\mu$-CT test did not undergo any special preparation.



Figure 3

Dispersion graph for compressive resistance of TS at 7 days

\subsection{Compressive strength test}

For testing the axial compression strength of the $(2 \times 4) \mathrm{cm}$ specimens, a servo electrical universal testing machine with a capacity of $30 \mathrm{kN}$ was used, with a special universal joint suitable for the CP and a load cell with full scale of $10 \mathrm{kN}$.

For the $(5 \times 10) \mathrm{cm}$ specimens, servo electrical universal testing machine with a capacity of $300 \mathrm{kN}$ was used, with a special universal joint suitable for the $\mathrm{CP}$ and a load cell with full scale of $300 \mathrm{kN}$. In both cases, the loading speed used was $(0.25 \pm 0.05) \mathrm{MPa} / \mathrm{s}$, as specified in NBR 7215 [8], with all test specimens being tested at 7 days, since the greatest gains in compressive strength of $\mathrm{CP}$ $\mathrm{V}$ occur until this age [10].

\subsection{Helium and mercury pycnometry tests}

The helium pycnometry tests were performed with the QUANTACROME STEREOPYCNOMETER - Model SPY-3, using the lower volume sample holder.

The mercury picnometry was performed in a volumetric flask with a capacity of $100 \mathrm{~mL}$. For the TS with dimensions of $(5 \times 10) \mathrm{cm}$, the test was performed in two stages, the first one being the fragments from the upper part of the $\mathrm{CP}($ part $1 \mathrm{~A})$ and the fragments from the lower part (part 2A).

Based on the real density and volumetric density figures, obtained from the helium and mercury pycnometry tests respectively, the porosity of the material at the ages of 7 and 28 days was calculated.

\subsection{Obtaining $\mu$-CT images}

A high-resolution microtomograph, model SkyScan 1172, was used to perform X-ray computed microtomography tests. This equipment has a CCD camera with a resolution of $10 \mathrm{Mp}$ (megapixel), X-ray tube that operates within a voltage range of 20 to 100 $\mathrm{kV}$ and a power of up to $10 \mathrm{~W}$. For the scanning of the images, a resolution of $(2000 \times 1048)$ pixels and $\mathrm{Al}+\mathrm{Cu}$ filter. A rotation was adopted at angles of up to $180^{\circ}$, in steps of $0.40^{\circ}$.

The readings were performed at 7 and 28 days. After the first reading, the specimen was packed in PVC film and conditioned in a humid chamber until 28 days, and a new reading was performed at this age. For each reading age, approximately 450 projections from the scanned portion of the sample were obtained. The NRecon software was used for the reconstruction of the images, being generated 1000 sections on average. The CTAn software [12] was used to calculate the porosity of each section.

The percentages of porosity presented represent an overall mean of the porosity values obtained for sections generated from reading with the microtomograph (1042 sections for reading at 7 days and 1038 sections for reading at 28 days), and the error was calculated from the standard deviation between the readings of the sections, within a $95 \%$ confidence interval.

\section{Results and discussions}

\subsection{Compressive strength}

Figure 3 shows the dispersion graph for the compressive strength 
Table 4

Statistic referential of the specimens' compressive strength on the 7h day

\begin{tabular}{|c|c|c|}
\hline Parameter & $\mathbf{( 5 \times 1 0 )} \mathbf{~ c m}$ & $\mathbf{( 2 \times 4 )} \mathbf{~ c m}$ \\
\hline Minimum (MPa) & 34.64 & 34.43 \\
\hline Maximum (MPa) & 43.28 & 48.11 \\
\hline Mean (MPa) & 38.86 & 39.97 \\
\hline Median (MPa) & 39.05 & 39.87 \\
\hline Standard deviation & 2.17 & 2.96 \\
\hline Coefficient of variation (\%) & 5.6 & 7.4 \\
\hline
\end{tabular}

results of the specimens. It is observed that TS that reached resistance greater than $40 \mathrm{MPa}$ belong, for the most part, to the group with dimensions of $(2 \times 4) \mathrm{cm}$. The largest individual values of compressive strengths also belong to specimens of said group.

Table 4 presents the values for statistical reference of the compressive strengths. Note that the $(2 \times 4) \mathrm{cm}$ and $(5 \times 10) \mathrm{cm}$ test specimens presented very close values for the lowest resistance, however the maximum resistance value of the CP $(2 \times 4) \mathrm{cm}$ was much higher. This also showed a higher mean resistance and a higher standard deviation of the results. For both CP groups, the median value was very close to the mean value, which indicates a distribution curve very close to the Normal distribution.

From the values of mean resistance and standard deviation, the coefficient of variation of Pearson (cv) was calculated, being the largest value presented by the group of TS with dimensions of $(2 \times 4) \mathrm{cm}$. The $\mathrm{cv}$ indicates the variability of the results (standard deviation) in relation to the mean. The lower the value, the more uniform the data.

For the analysis of the TS mean resistance values, the hypothesis test was applied, based on the Student's T-probability distribution (or statistical test $\mathrm{T}$ ) for independent samples. This test is used to assess whether there is a significant difference in the mean of a measure between two groups. The null hypothesis is that the mean is equal in both groups. The alternative hypothesis is that the mean is different. If the $p$-value, probability of error in rejecting the null hypothesis, is less than $5 \%$, the null hypothesis is rejected. That is, it is assumed that the mean is different in the two groups.

In the case of this study, the p-value found was $2.7 \%$, indicating that there is a significant difference between the compressive strength of the two groups, being the $(2 \times 4) \mathrm{cm}$ cylinder resistance greater. Thus, although the average values of resistance are very close (difference of $1.11 \mathrm{MPa}$ ), the statistical difference between the resistances is quite significant.

For comparison, a new hypothesis test was performed using the Fisher-Snedecor probability distribution test ( $F$ test) for the comparison of variance. A p-value of $0.024(2.4 \%)$ was obtained, again indicating that the variability of the $(2 \times 4) \mathrm{cm}$ TS

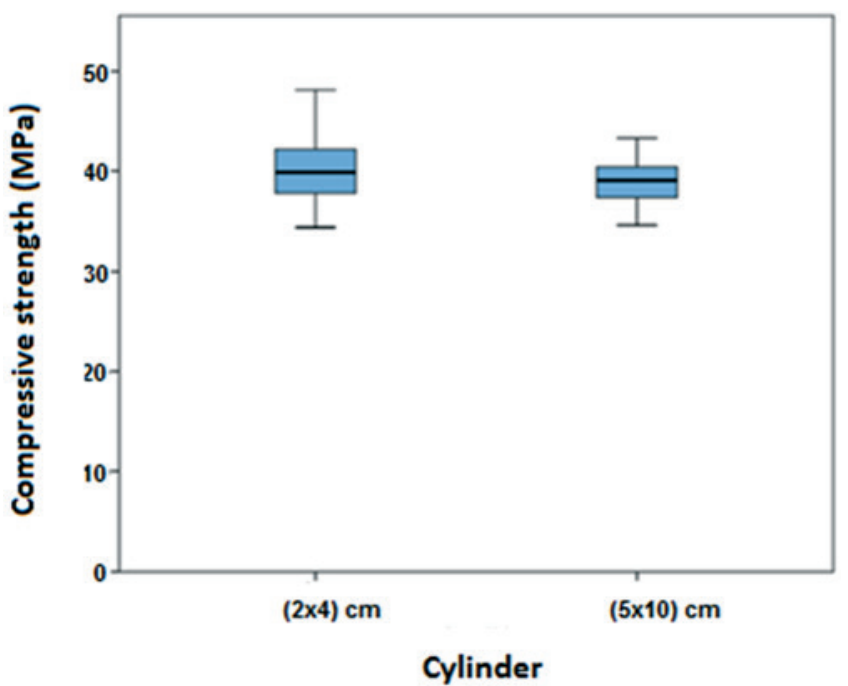

Figure 4

Boxplot for compressive strength distribution of cylinders

is significantly greater than the $(5 \times 10) \mathrm{cm} \mathrm{TS}$.

Figure 4 shows the boxplot ${ }^{1}$ of distribution of resistance for the two specimens groups. It is possible to observe that the variability of the resistance using the cylinder $(2 \times 4) \mathrm{cm}$ is larger, in relation to the $(5 \times 10) \mathrm{cm}$ cylinder.

Figure 5 shows the frequency distribution of the percentage of TS per compressive strength class. Note that the highest percentage assumed by the $(5 \times 10) \mathrm{cm}$ TS was the class of 39 $\mathrm{MPa}$. For the TS of $(2 \times 4) \mathrm{cm}$ was the class of $41 \mathrm{MPa}$.

The higher average compressive strength and greater dispersion in the results presented by the TS with dimensions of $(2 \times 4) \mathrm{cm}$ are justified by the scale effect, that is, there is a decrease in the axial compressive strength with the increase of the size of the specimen. This effect is insignificant in large structures, but with great influence in small ones, as is the case of the specimens [13].



Figure 5

Frequency distribution of TS percentage per compressive strength class 
Table 5

Porosity percentage

\begin{tabular}{|c|c|c|c|c|c|}
\hline \multirow{2}{*}{ Technique } & Specimen (cm) & \multicolumn{2}{|c|}{ 7 days (\%) } & \multicolumn{2}{|c|}{ 28 days (\%) } \\
\hline \multirow{4}{*}{ Pycnometry } & $2 \times 4$ & 16.1 & \pm 0.5 & 16.4 & \pm 0.6 \\
\cline { 2 - 6 } & $5 \times 10(1 \mathrm{~A})$ & 18.3 & \pm 0.2 & 18.4 & \pm 0.1 \\
\cline { 2 - 6 } & $5 \times 10(2 \mathrm{~A})$ & 18.6 & \pm 0.2 & 19.4 & \pm 0.1 \\
\cline { 2 - 6 } & $5 \times 10(1 \mathrm{~A}+2 \mathrm{~A})$ & 18.6 & \pm 0.4 & 18.7 & \pm 0.2 \\
\hline H-CT & $2 \times 4$ & 36.4 & \pm 0.1 & 16.9 & \pm 0.1 \\
\hline
\end{tabular}

$1 \mathrm{~A}$ - fragments from the upper-half of specimen ; $2 \mathrm{~A}$ - fragments from the lower-half of specimen; $1 \mathrm{~A}+2 \mathrm{~A}-\mathrm{Porosity}$ calculated based on mean volumetric density values.

\subsection{Porosity by He and $\mathrm{Hg}$ pycnometry and $\mu-\mathrm{CT}$}

Table 5 presents the porosity percentages, calculated from the pycnometry techniques and the readings with the $\mathrm{X}$-ray microtomograph.

The porosity of the samples, by the method of picnometry, was calculated from the values of real density and volumetric density, obtained by the helium and mercury pycnometry tests, respectively.

The porosity results, obtained by the $\mu$-CT technique, were calculated from the global average of the porosity values obtained for each section generated by the reading with the microtomograph, being 1042 sections for reading at 7 days and $1038 \mathrm{sec}-$ tions for reading at 28 days.

By the pycnometry technique, it was observed that the percentages of porosity obtained for the specimens with dimension of $(2 \times 4) \mathrm{cm}$ were smaller than those presented by the TS with dimension of $(5 \times 10) \mathrm{cm}$.

Although changes in the porosity of cementitious materials are normally expected with advancing age, caused by changes in its microstructure due to the process of hydration of the cement, the variation of the results, by the picnometry technique, was not significant. This result can be a consequence of an accelera-

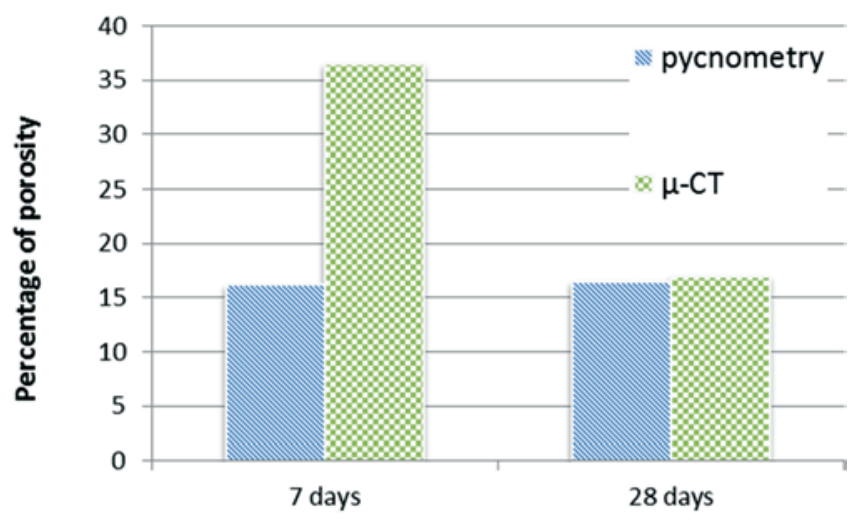

Test Age

\section{Figure 6}

Porosity values obtained by $\mu$-CT and helium and mercury pycnometry tion of hydration process, caused by oven dried the samples, at a temperature of $(105 \pm 5)^{\circ} \mathrm{C}$. $[14,15]$

However, the $\mu$-CT, whose the TS analyzed did not undergo a drying process, not only indicated a large reduction in the porosity of the material at 28 days, but also a higher percent porosity at the age of 7 days, compared to the result obtained by the picnometry technique for the $(2 \times 4) \mathrm{cm}$ TS. At the age of 28 days, the porosity values between the techniques were very close.

According to Cervera et al. [16], to take into account the influence of temperature, many aging models have been based on the concepts of "maturity" or "equivalent age" by defining an artificial age for the cementitious material. This artificial age may be higher or lower than the actual age depending on whether the temperature history has accelerated or delayed the maturation process.

\subsection{Evaluation of results}

The greater variability in results and higher mean compressive strength presented by the smaller test specimens are in line with the behaviors reported in studies on the subject [7, 17-21], and can be explained especially by the theory Of Effect Size [19, 20].

Beyond that, it should be taken into account that the mechanical strength of a cementitious matrix composite is significantly affected by the porosity of its internal structure [21]. Thus, the lower porosity of the $(2 \times 4) \mathrm{cm}$ TS corresponds to a higher average compressive strength, in relation to the TS of $(5 \times 10) \mathrm{cm}$.

The comparison of the porosity results, obtained from the $\mu$-CT and pycnometry techniques, is presented in Figure 6. Although the porosity results, presented by the two techniques, were very different at the age of 7 days, at 28 days these were close. This behavior accentuate the hypothesis that the use of the drying temperature of the samples for the pycnometry test may have affected the pore structure of the material, especially at the age of 7 days, leading this to assume a pore structure characteristic of more advanced ages $[15,16]$.

\subsection{Microtomography images}

Figure 7 shows images generated from the $\mathrm{X}$-ray microtomograph readings at randomly selected ages of 7 and 28 days. Note that the geometry proposed for the test specimen allowed a satisfactory resolution to be obtained, and it is possible to visualize the reduction in the porosity of the sections at 28 days. 



\section{Figure 7}

Selection of tomographic sections of specimen

\section{Conclusions}

For the $\mu-C T$ equipment used in this study, the adoption of test specimens with dimensions of $(2 \times 4) \mathrm{cm}$ was fesible, indicating that studies on the pore structure of the cementitious composite can be performed in an intact whole structure. It should be noted that equipment with lower resolution and power than the one used in this study may not present satisfactory results for the TS dimensions considered.

According to the statistical tests, it was verified that, in the test of compressive strength, the test specimens of $(2 \times 4) \mathrm{cm}$ presented greater variation of results and a higher average resistance, compared to the test specimens of $(5 \times 10) \mathrm{cm}$, although its average resistances are very close. Such behavior is compatible with the results obtained by several studies on the influence of dimensional variation on test specimens.

The percentage of porosity, calculated from the density values obtained by the helium and mercury picnometry tests, was slightly lower for the test specimen of $(2 \times 4) \mathrm{cm}$. Since the compressive strength is affected by the porosity of the material, in an inversely proportional relation, the greater average resistance to compression presented by this test body is consistent.
The study showed that the comparison of porosity results obtained from the techniques of picnometry and microtomography may be feasible [2, 23], however, the sample preparation process should be reevaluated, especially with regard to the use of temperature for drying the material at earlier ages, since the procedure was feasible for the age of 28 days, but influenced the results at 7 days. The large number of studies addressing the pore microstructure of cementitious materials, and especially the use of $\mu-C T$, emphasizes the need to elaborate a procedure for the preparation of specimens with reduced dimensions. Although there is no obligation to follow technical standards in research, and each researcher has the freedom to define the procedures to be followed, trying to create a reference standard for microtomography studies can help the scientific community achieve greater advances, once that the scale effect, sample preparation and sampling technique have a direct correlation in the compressive strength and the pore structure of the material, which can create great difficulties in comparing the results.

\section{Acknowledgments}

The authors thank CNPq and FAPEMIG for financial support and HOLCIM for the supply of the cement used in this research. 


\section{Bibliographical references}

[1] V. Cnudde, M. Boone, J. Dewanckele, M. Dierick, L. Van Hoorebeke, P. Jacobs, 3D Characterization of sandstone by means of X-ray computed tomography. Geosphere, v.7, n.1, p. 54-61, February 2011.

[2] E.E. Bernardes, A.G. Magalhães, W.L. Vasconcelos, E.H.M. Nunes, Evaluation of the effect of varying the workability in the concrete pore structure by using X-ray microtomography. RIEM, 6 (4), august (2013), 582-597.

[3] M. Lánzon, V. Cnudde, T. Kock, J. Dewanckele, X-ray Microtomography $(\mu-\mathrm{CT})$ to evaluate microstructure of mortars containing low density additions. Cement \& Concrete Composites, 34 (9) (2012), 993-1000.

[4] S. Lu, E.N. Landis, D.T. Keane, X-ray Microtomographic studies of pore structure and permeability in Portland cement concrete. Materials and Structures, 39 (6) (2006), 611-620.

[5] E. Gallucci, K. Scrivener, A. Groso, M. Stampanoni, G. Margaritondo, 3D experimental investigation of the microstructure of cement pastes using synchroton X-ray microtomography ( $\mu \mathrm{CT})$, Cement and Concrete Research 37 (3) (2007), 360-368.

[6] N.N. Naik, K.E. Kurtis, A.P. Wilkinson, A.C. Jupe, S.R. Stok, Sulfate deterioration of cement-based materials examined by $x$-ray microtomography. Proc. SPIE 49th Annual Meeting, Optical Science and Technology: Developments in X-ray Tomography: IV. Denver, August 2- 6, 2004.

[7] E.N. Landis, E.N Nagy, D.T. Keane, Microtomographic Measurements of internal damage in Portland-cement-based composites. Journal of Aerospace Engineering, 10 (1) (1997), 2-6.

[8] ABNT - Associação Brasileira de Normas Técnicas. NBR 7215 (Incorpora a Errata n 1 de 1997): Cimento Portland Determinação da resistência à compressão. Rio de Janeiro, 1996.

[9] ABNT - Associação Brasileira de Normas Técnicas. NBR 5738: Concreto - Procedimento para moldagem e cura de corpos de prova. Rio de Janeiro, 2003

[10] ABNT - Associação Brasileira de Normas Técnicas. NBR 5733 /EB-2: Cimento Portland de alta resistência inicial. Rio de Janeiro, 1991.

[11] ABNT - Associação Brasileira de Normas Técnicas. NBR 7214: Areia Normal para ensaio de cimento - Especificação. Rio de Janeiro, 2012.

[12] SkyScan, Structural parameters measured by SkyScan CTanalyser software. August 1, 2009.

[13] C.V.G, Coura; M.T.G, Barbosa; F.A.I, Darwish, Análise da lei de Bažant e de Carpinteri na resistência à compressão do concreto. Revista Internacional de Desastres Naturales, Accidentes e Infraestructura Civil, v.8, n.1, mayo, 2008.

[14] M. Alshaaer, H. Cuypers, G. Mosselmans, H. Rahier, J. Wastiels, Evaluation of a low temperature hardening Inorganic Phosphate Cement for high-temperature applications. Cement and Concrete Research 41 (1) (2011), 38-45.

[15] K.K. Aligizaki, Pore structure of cement-based materials: testing interpretation and requirements. Modern concrete technology series; v 12. London; New York Taylor \& Francis, 2006

[16] M. Cervera; R. Faria, J. Oliver; T. Prato, Numerical modelling of concrete curing, regarding hydration and temperature phenomena. Computers and Structures 80 (2002), 1511-1521.

[17] S-T. Yi, E-I. Yang, J-C, Choi, Effect of specimen sizes, specimen shapes and placement direction on compressive strength of concrete. Nuclear Engineering and Design, January, 2006 v. 236, n.2, p.115-127.

[18] R.L. Day, M.V. Haque, Correlation between strength of small and standard concrete cylinders. ACI Materials Journal, v.90, n. 5, p. 452-462, 1993.

[19] J.R. Viso; J.R. Carmona; G. Ruiz, Shape and size effects on the compressive strength of high-strength concrete. Cement and Concrete Research 38 (3) (2008), 386-395.

[20] C.V.G. Coura, M.T.G. Barbosa, F.A.I. Darwish, Análise da lei de Bažant e de Carpinteri na resistência à compressão do concreto. Revista Internacional de Desastres Naturales, Accidentes e Infraestructura Civil, v8, n.1, mayo, 2008.

[21] C.A. Gutschow, A avaliação da resistência do concreto em estruturas acabadas através da extração e ensaio de testemunhos de pequenos diâmetros. Dissertação de Mestrado. Universidade Federal do Rio Grande do Sul, Porto Alegre, 1995. $146 \mathrm{p}$.

[22] C. Lian, Y. Zhuge, S. Beecham, The relationship between porosity and strength for porous concrete. Construction and Building Materials, 25 (11), p. 4294-4298, 2011.

[23] S.T Ho, D.W. Hutmacher, A comparison of micro CT with other techniques used in the characterization of scaffolds. Biomaterials 27 (8) (2006), p. 1362-1376. 